\title{
Commercial Profitability of Poplar Plantation with Reference to the Damages Caused by Fungi
}

Ljiljana Keča

Faculty of Forestry University of Belgrade Kneza Višseslava 1 11030 Belgrade

Serbia

E-mail: ljiljana.keca@sfb.bg.ac.rs

\section{Abstract}

Background and purpose: Due to the fact that poplar rotation is one of the shortest in forestry, and as production of poplar wood requires rational and well-planned management, the potentials of sites and species must be maximally utilised. The main characteristics of the procedure of investment in poplar cultivation, is the fact that the conditions for the beginning of production and their exploitation are not created simultaneously. The main goal of the work reported in this paper was to examine the financial effects of different discount rates on the cost-efficiency values of studied poplar plantation, based on an analysis of the present value of costs and revenues over a stated time period using different methods of investment appraisal.

Material and methods: Investment Appraisal also known as Capital Budgeting is used to asses whether capital expenditure on particular poplar plantations will be beneficial for the entity or not. The investigated plantation was established from Populus $\mathrm{x}$ euramericana cl.l-214 on alluvial semigley, with planting spacing 6 x $3 \mathrm{~m}$, aged 26 years, for technical wood production. The data used in this study were collected from the archives of the, according to the age at plantation established and from the management and materials books of the forest enterprise "Vojvodinašume". During twoyear study, the material was collected from study plot in order to assess the density, distribution and significance of individual fungal organisms present in the plantation. Identification was based on the morphological characteristics of species.

\author{
Nenad Keča \\ Faculty of Forestry \\ University of Belgrade \\ Kneza Višeslava 1 \\ 11030 Belgrade \\ Serbia
}

Results and conclusions: Under the calculation discount rate of $12 \%$, the project for the production cycle of 26 years was not cost-effective from the economic aspect. The discount rate of $6 \%$ can be accepted in this studied plot because of the better sites (alluvial semigley) and youngness of the stand. For the studied sample plot IRR is 6.94. $R$ for the $r=12 \%$ in the study compartment is 0.407 . The analysis shows that PBP is practically unacceptable for the investor under the discount rate of $6 \%$. In the studied plot altogether 11 species of fungi causing significant damages in hybrid poplar plantations were identified. Two were found on cortical tissue, 6 on leaves and 3 species are causing decay. Number of trees attacked with decaying fungi, like Fomes fomentarius, Trametes suaveolens, was bellow $2 \% /$ two percentage.

Keywords: hybrid poplar plantations, investment appraisal, commercial profitability, costs, revenues, diseases, decline.

\section{INTRODUCTION}

The economics of growing hybrid poplar is a difficult subject that has been studied by many for years, but it depends upon so many ever-changing variables [1-6]. It is complex because the revenues from a multiyear poplar crop are not generated until harvest and the costs to establish and maintain the crop occur long before rotation age [5]. Moreover, the costs vary markedly with soil type, productivity, location including distance from markets, fossil fuel costs, government programs and landowner objectives. There are 
also many risks in growing poplars including weather, pests and diseases [4]. Poplar plantations are a category of fixed assets in forestry, i.e. the assets with a biological character [7-9]. The commodity nature of most forest plantation products - either fibre for pulp production, or utility grade timber - or the increasing globalisation of markets for these products maintains strong price pressure in favour of the lowest cost producers. Production costs are determined by the inescapable trio of land, labour and capital costs, and by forest productivity. The inevitable consequence of these pressures is the trend towards shorter crop rotations, which have been facilitated by advances in processing technologies, and the search for enhanced productivity [10].

Due to the fact that production of poplar wood requires rational and well-planned management, the site and the species potential have to be maximally utilised. Also it is very important to realize the favourable financial effects of such a production. Poplar wood production in plantations of different characteristics is one of the shortest rotations in our circumstances [8]. They are related to their site, cultivated for a relatively long time and have a relatively long utilisation cycle, with the yield development determined by the plantation growth and age.

The investment process in poplar wood production includes financial investments in present to achieve economic benefits in the future, and have seasonal characteristics. Plantations transfer their value gradually to the obtained products during the period of their harvesting, and, by the realisation of the products, the means invested in the plantation establishment are reproduced $[9,10]$. Therefore, it is possible some problems can arise, mainly in a framework of forecasts, calculation of investments in poplar production, engagement of human labour, mechanical work, etc. [11].

Yield classes in hybrid poplar plantations $(P . x$ euramericana Cl. 1-214) are high in Serbia. But, the economic cost-effectiveness of the poplar plantations is debatable, due to the high costs encountered at the stage of plantation establishment (chipping of tree stumps, ploughing, planting, protection, etc.) [12].

Presence of pests and diseases can cause reduction of increment and vitality in fast growing hybrid poplar plantations [13]. Depending on the environmental conditions and inoculums potential of pathogenic or saprophytic fungi damages can vary from year to year [14]. Appropriate use of pesticides and less susceptible cultivars can minimize losses of production. Cultivar $1-214$ is very productive, but requires optimal conditions and very intense protection against pests and diseases, especially Cryptodiaporthe populea (Sacc.) Butin [15] and leaf diseases [16].

The goals of the work reported in this paper were: (i) to examine the financial effects of different discount rates on the cost-efficiency values of poplar plantations, based on an analysis of the present value of costs and revenues over a stated time period, (ii) to assess influence of pests to the financial outcomes of plantation and (iii) to test the sensitivity of these values to possible changes in the levels of costs and revenues.

\section{MATERIAL AND METHODS}

The period of investments in poplar growing can be relatively long, and so is the period of harvesting. Therefore, it is important to determine the time of return the capital (pay back period - PBP) invested in these and similar plantations, current value of cash flow which is equal to the current value of the cast outflow (internal rate of return - IRR), difference between current values of the future incomes and costs of the projected plantations (net present value - NPV), and value the degree of profitability when we compare the degree of incomes and outcomes (benefitcost ratio $-R$ ).

The data used in this study were collected in two, main phases. Data pertaining to costs during years 0-5 (soil preparation, planting, care and protection, etc.) were obtained from the archives of the forest enterprise which managed the studied plantations Public Forest Enterprise "Vojvodinašume", according to the age at plantation established [8-12].

Cash outflow is present in the first 5 years, and cash inflow from schematic thinning in 6th years and at the end of rotation (in this case at age 26) (Table 1 ). In the second phase data were collected from the management and materials books of the forest enterprise. Costs and receipts of wood production of the clone poplar I-214 were investigated in one management unit in (F.E. "Sremska Mitrovica”, PE "Vojvodinašume"). The stand 26 years old, planting density $6 \times 3 \mathrm{~m}$, forest type poplar on alluvial semigley, with a total area of 9.78 ha (Map 1). The purpose of this stand is production of technical wood. Costs are expressed per unit area 1 ha at the prices in force in January 2010, converted into euro $(€)$. Since, all studied stands are state-owned and managed by the Public Forest Enterprise "Vojvodinašume", the value (cost) of the land (land rent) did not enter into the calculations [17].

The aim of the study was to check the justification of the invested financial means in artificial poplar 


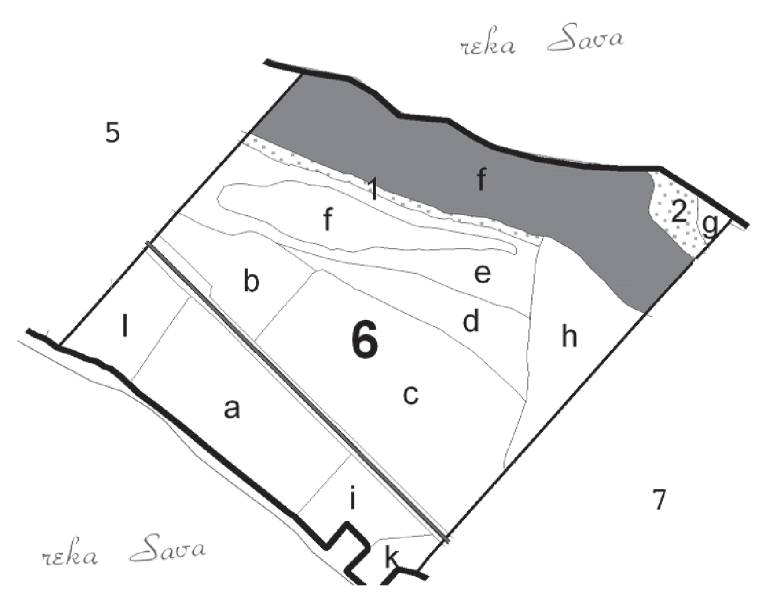

MAP 1

Studied plot (compartment $f$ )

plantations, based on the analysis of costs and receipts in the rotation of 26 years, on alluvial semigley, at different discount rates $(4-12 \%)$, by using the method of analysis of commercial profitability, especially some methods of dynamic investment calculation (NPV, IRR, R, PBP) [12].

The NPV method calculates the present values for all future cash flows $[12,18,19]$.To determine the value of the discount rate at which NPV investment is zero, it has been used IRR. Payback period calculates the time taken by a project to recoup the initial investment $[12,20]$. All benefits and costs should be expressed in discounted present values i.e. benefitcost ratio $[12,21]$.

Sensitivity analysis is useful for adjustment of changes in current values of costs and receipts in a range $70-130 \%$. Using this analysis clearly is defined changes in financial profitability of the raising of poplar plantations; however it can be obtained the results which point out the positive or negative effects. It can be useful in forestry practice to channel management activities to find out the solution for achievement of the best results in a framework of financial results [22].

The dynamic methods are nowadays used in all countries over the world in the investment economics effectiveness appraisal and start with the assumption that money has its time value, i.e. the certain amount of money does not have the same value today and in a certain future moment of time, which is very important particularly in forestry where the rotations are very long.

During two-year study, the material was collected from study plot in order to assess the density, distribution and significance of individual fungal organisms present in the plantation. Identification was based on the morphological characteristics of species as described by Keča [23]. The estimation of damages caused by different species was according to the Karadžić [24].

Treatment costs consisted of the product price and labour cost. The cost of labour and mechanization was estimated directly in the field and added to the cost of establishment and maintenance of plantation.

\section{RESULTS}

The access to the main data (Table 1) point out the duration of rotation period is 26 years; stand costs are present in first 6 years and in the $26^{\text {th }}$ year of the stand (final cut). In the age of seventh there is small income, and on the end of the rotation we have pre final income of $16236.58 €$ ha $^{-1}$.

Net present value, by the discount rate of $12 \%$ is $N P V=\sum P_{r}-\sum T_{r}=-1585.84 € h a^{-1}$. Based on this fact it

\section{TABLE 1}

Assortment structure and income from the studied poplar plantation

\begin{tabular}{|c|c|c|c|c|}
\hline \multirow{2}{*}{ Classes } & \multicolumn{2}{|c|}{ Assortment structure } & Price & Value of assortments by official price list \\
\cline { 2 - 5 } & $\mathrm{m}^{3}$ & $\mathrm{~m}^{3} \cdot \mathrm{ha}^{-1}$ & $€ \cdot \mathrm{m}^{-3}$ & $€ \cdot \mathrm{ha}^{-1}$ \\
\hline F veneer & 1524.51 & 154.46 & 55.00 & 8495.24 \\
\hline L-peeling logs & 759.70 & 76.97 & 45.00 & 3463.68 \\
\hline Timber wood class I & 545.66 & 55.28 & 35.00 & 1934.96 \\
\hline Timber wood class II & 493.22 & 49.97 & 27.50 & 1374.22 \\
\hline Pulpwood & 557.69 & 56.50 & 17.14 & 968.47 \\
\hline Total & 3880.78 & 393.19 & $/$ & 16236.58 \\
\hline
\end{tabular}


can be concluded that the project is not profitable for the rotation of 26 years and discount rate of $12 \%$, due to the fact that it is in the loss of approximately $1600 €$ on the end of the rotation (Table 2). However, it could be find the solution in calculation with the lower discount rate or investigate the possibility to short the rotation.

Based on the application of the susceptibility analysis, it was concluded that there was an option to realise the positive financial effect by decreasing the costs, or by increasing the receipts. Sensitivity analysis show how the project is responding to cost and receipts changes by varying of cost/receipts in the range of $\pm 30 \%$ (in the step of $5 \%$ ). The future of the project can be clearly defined by using this method in the framework of risk analysis (Table 3 ).

It has been determined that for the $r=12 \%$, project is profitable if it can be realise the incomes more than 2.1 times (330\%) or to reduce costs for $56 \%$. For $r=8 \%$ it is necessary to diminish costs for $12 \%$ and in that case investment can cover costs from incomes. Alternative way is than in the current circumstances, income can be increase for about $18 \%$. For $r=6 \%$ by the current circumstances and receipts, it is necessary to increase costs for about $15 \%$ and in that case investment can cover the costs from the incomes. It is possible to reach the same financial effect by decreasing of incomes for about $12 \%$. For $r=4 \%$ it is possible that investment can cover the costs from the incomes for the increasing of the costs for about $55 \%$. By the current costs and present situation it can increase of the incomes for $36 \%$ (64\% from realised) try to supply the same financial effect. The results clearly direct to the fact there is the reverse proportion between the discount rate and age of the stand (Table 3 ).

Internal rate of return is 6.94 . It can be concluded that the annual rate of profit is just $6.94 \%$ from the whole capital expenditures. Due to this fact it can be concluded that this project cannot pay off the potential loan and the solution can be find in reduction of discount rate on less than $6.94 \%$. Sensitivity analysis shows that the stand is very susceptible to changes of incomes and outcomes. Decreasing of costs and increasing of revenues for $30 \%$, value if IRR ranged 9.26 $\left(T_{r}\right)$ and $8.64\left(P_{r}\right)$ (Table 4).

In this sample plot there has not been noticed the values of IRR higher than $12 \%$ in researched interval of changes in costs and revenues. They are realized in the level below $70 \%$ from realized costs $(\leq 46.7 \%)$ or above $130 \%$ from realized revenues ( $\geq 213.9 \%$ ).

Benefit - cost ratio for the $r=12 \%$ in the researched plot range of $\mathrm{Tr}$ and $\mathrm{Pr}$ is lower than 1. In the study compartment this ratio is 0.407 . Accordingly, it can be asserted that it is economically unjustified to invest in the projected stand, but only in the case when the value of social capital accounts for $12 \%$. Based on the analysis of sensitivity of the cost-benefit method, it was concluded that cost benefit ratio for $r=8-12 \%$ was below 1 within the study range of costs and receipts changes, while for $r=4-6 \%$ this ratio was above 1 in some cases of decrease in costs, i.e. increase in receipts. It was noted that the change in $p$ depending on the change in costs, developed by the exponential function, and the change in $r$ depending on the change in receipts developed by

TABLE 2

Receipts and costs of the wood production project in poplar plantation for $r=12 \%$

\begin{tabular}{|c|c|c|c|c|c|c|c|}
\hline \multirow{3}{*}{ Year } & Costs & Receipts & Real C & Real T & Cost & Receipts & \multirow{2}{*}{$\sum \operatorname{Pr}-\sum \operatorname{Tr}$} \\
\hline & $\mathrm{T}$ & $\mathrm{P}$ & $T_{r}$ & $\mathrm{P}_{\mathrm{r}}$ & $\sum \mathrm{T}_{\mathrm{rs}}$ & $\sum \mathrm{P}_{\mathrm{rs}}$ & \\
\hline & \multicolumn{7}{|c|}{$€$} \\
\hline 0 & 2040.48 & 0 & 2040.48 & 0 & 2040.48 & 0 & -2040.48 \\
\hline 1 & 209.44 & 0 & 187.00 & 0 & 2227.48 & 0 & -2227.48 \\
\hline 2 & 177.97 & 0 & 141.88 & 0 & 2369.36 & 0 & -2369.36 \\
\hline 3 & 111.65 & 0 & 79.47 & 0 & 2448.83 & 0 & -2448.83 \\
\hline 4 & 96.9 & 0 & 61.58 & 0 & 2510.41 & 0 & -2510.41 \\
\hline 5 & 96.9 & 0 & 54.98 & 0 & 2565.39 & 0 & -2565.39 \\
\hline 6 & 442.22 & 1064.2 & 224.04 & 539.16 & 2789.43 & 539.16 & -2250.28 \\
\hline 26 & 3585.44 & 16236.34 & 188.31 & 852.75 & 2977.74 & 1391.90 & -1585.84 \\
\hline$\Sigma$ & / & / & 2977.74 & 1391.90 & & & $-1,59$ \\
\hline
\end{tabular}


TABLE 3

Susceptibility of NPV depending on relative changes of $T_{r}$ and $P_{r}(r=4-12 \%)$

\begin{tabular}{|c|c|c|c|c|c|c|c|c|}
\hline \multirow{2}{*}{ Rate of change } & \multicolumn{2}{|c|}{$r=12 \%$} & \multicolumn{2}{|c|}{$r=8 \%$} & \multicolumn{2}{|c|}{$r=6 \%$} & \multicolumn{2}{|c|}{$r=4 \%$} \\
\hline & $T_{r}$ & $P_{r}$ & $T_{r}$ & $\mathrm{P}_{\mathrm{r}}$ & $T_{r}$ & $P_{r}$ & $\mathrm{~T}_{\mathrm{r}}$ & $P_{r}$ \\
\hline$\%$ & \multicolumn{8}{|c|}{$000 €$} \\
\hline 70 & -0.69 & -2.00 & 0.50 & -1.37 & 1.70 & -0.72 & 3.68 & 0.38 \\
\hline 75 & -0.84 & -1.93 & 0.33 & -1.23 & 1.51 & -0.50 & 3.46 & 0.71 \\
\hline 80 & -0.99 & -1.86 & 0.16 & -1.08 & 1.33 & -0.28 & 3.25 & 1.05 \\
\hline 85 & -1.14 & -1.79 & 0.00 & -0.94 & 1.14 & -0.07 & 3.03 & 1.38 \\
\hline 90 & -1.29 & -1.73 & -0.17 & -0.80 & 0.95 & 0.15 & 2.82 & 1.72 \\
\hline 95 & -1.44 & -1.66 & -0.34 & -0.65 & 0.77 & 0.36 & 2.60 & 2.05 \\
\hline 100 & -1.59 & -1.59 & -0.51 & -0.51 & 0.58 & 0.58 & 2.39 & 2.39 \\
\hline 105 & -1.73 & -1.52 & -0.68 & -0.37 & 0.39 & 0.80 & 2.17 & 2.72 \\
\hline 110 & -1.88 & -1.45 & -0.85 & -0.22 & 0.21 & 1.01 & 1.96 & 3.06 \\
\hline 115 & -2.03 & -1.38 & -1.02 & -0.08 & 0.02 & 1.23 & 1.74 & 3.39 \\
\hline 120 & -2.18 & -1.31 & -1.19 & 0.06 & -0.17 & 1.44 & 1.52 & 3.73 \\
\hline 125 & -2.33 & -1.24 & -1.35 & 0.21 & -0.35 & 1.66 & 1.31 & 4.06 \\
\hline 130 & -2.48 & -1.17 & -1.52 & 0.35 & -0.54 & 1.88 & 1.09 & 4.40 \\
\hline $\begin{array}{l}\text { Condition for } \\
\Sigma P_{r}-\Sigma T_{r}=0\end{array}$ & 46.74 & 213.93 & 84.88 & 117.81 & 115.51 & 86.57 & 155.36 & 64.37 \\
\hline
\end{tabular}

the linear function Therefore it can be claimed that economically is unacceptable to invest in such a stand, but just when $r=12 \%$. Sensitivity analysis of $R$ was also carried out for $r=8-12 \%$ in the range of changes of costs and receipts lower than 1 . For $r=4-6 \%$ there are cases where this ratio is above 1 . Thus, it seems better to focus efforts on reducing the discount rate, respectively.

Statistical significance is verified by t-test, correlation coefficient, determination coefficient, and Fisher's statistics for changing of costs and receipts. It can be concluded that the connection of relative and independent variable very high $R \geq 0.94$, the ratio between explained and total variations in the regression is very high $R^{2} \geq 0.9$. Fisher test confirm i.e. test the precision of calculated correlation coefficient. That value is also very high, therefore it can be proven the fact that we can have confident in the calculated coefficient of cor-

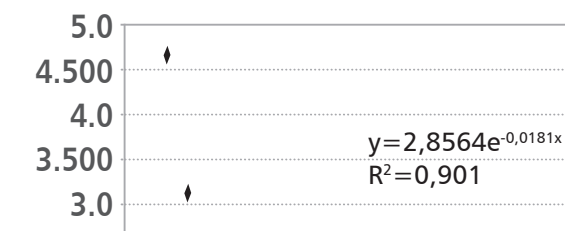

R 2.500

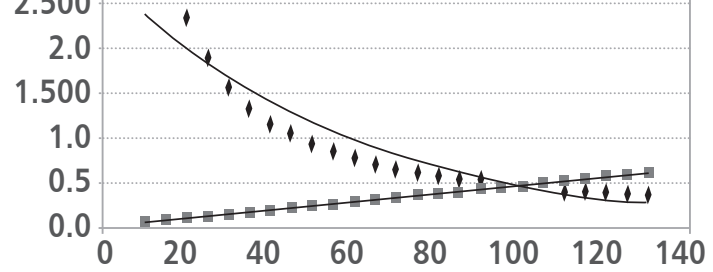

FIGURE 1 $(\%)$

Changes in the benefit-cost index $(R)$ in relation to relative changes in costs $\left(C_{r}\right)$ and revenues $\left(R_{r}\right)$ at the discount rate $r=12 \%$ for studied plot

\section{TABLE 4}

Sensitivity of IRR in a ratio changes of $T_{r}$ and $P_{r}$ in the range of $70-130 \%(r=12 \%)$

\begin{tabular}{|c|c|c|c|c|c|}
\hline$P_{r}$ & $T_{r}$ & IRR & $T_{r}$ & $P_{r}$ & IRR \\
\hline \multicolumn{7}{|c|}{$\%$} & 70 & 4.58 \\
\hline 100 & 70 & 9.26 & 100 & 130 & 8.64 \\
\hline $\begin{array}{c}\text { Condition for } \\
\text { IRR = 12\% }\end{array}$ & 130 & 5.22 & & $213.93 \%$ & \\
\hline
\end{tabular}


relation. Using t-test it is established the fact that the precision of the calculated parameters and it is proven that the parameters are very precise calculated in all examples (Table 5).

\section{TABLE 5}

Statistics analysis for the studied sample plot

\begin{tabular}{|c|c|c|c|}
\hline $\begin{array}{c}\text { Changes } \\
\text { of T }\end{array}$ & Values & $\begin{array}{c}\text { Changes } \\
\text { of } P\end{array}$ & Values \\
\hline$R$ & 0.949 & $R$ & 0.9999 \\
\hline$R^{2}$ & 0.901 & $R^{2}$ & 0.9999 \\
\hline F-statistics & 209.3 & F-statistics & 7928443 \\
\hline t-statistics & 10.67 & t-statistics & -0.51 \\
\hline \multicolumn{2}{|c|}{$y=2.856 \cdot \mathrm{e}^{-0,0181 \mathrm{x}}$} & \multicolumn{2}{|c|}{$\mathrm{y}=0.0047 \mathrm{x}+0.00007$} \\
\hline
\end{tabular}

Application of the pay back period $(P B P)$ calculation can affect greatly the reliability of predicting the degree of economic effectiveness of investments, and also the potential risks for the investor in his decisions on investments in poplar cultivation. In this procedure, the paper does not apply the recognized calculation rate of $12 \%$, which is usually applied worldwide, but the rates of $6 \%$, $4 \%$ and $2 \%$. The most favourable situation is the discount rate of $2 \%$, where the $P B P$ is 12 years. The analysis shows that $P B P$ is practically unacceptable for the investor under the discount rate of $6 \%$. The susceptibility of $P B P$ in this case was analysed by varying the costs within $10-100 \%$, and the receipts between $100-550 \%$. Based on the analysis of susceptibility for the method of pay back period, it can be concluded that the change in receipts and costs in 5\% steps can be represented by an exponential function and that $P B P$ is between 1.3-4.6 years. For $r=2 \%$ this ratio is the most favourable both in the case of the changes in receipts and the changes in costs [12].

Altogether 11 species of fungi causing significant damages in hybrid poplar plantations were identified. Two were found on cortical tissue, 6 on leaves and 3 species are causing decay. In one to two years old plantations trees were destroyed by Dothichiza populea and on dryer sites by Valsa sordida. Approximately $9 \%$ of costs for replanting of plantation were attributed to these two pathogens.

From the second year fungi attacking leaves Melampsora spp. and Marssonina brunnea directly influence diameter and height increment. Performed treatments with chemical agent Bakarni kreč - copper oxychloride (Zorka Šabac, Serbia) and captan fungicides reduced attack to moderate, so there was no significant reduction in biomass production.

Number of trees attacked with decaying fungi, like Fomes fomentarius, Trametes suaveolens, was bellow $2 \%$ two percentage (Table 6). Trees with decay could not be used for assortment production, which caused decrease of revenues. On the other hand decayed trees were used for biodiversity sustain, which is obligatory in FSC certified forests.

\section{TABLE 6}

Diseases causing decline in poplar plantations establishment and protection

\begin{tabular}{|c|c|c|c|}
\hline No. & Species & Plant parts colonized & Significance \\
\hline 1. & $\begin{array}{c}\text { Cryptodiaporthe populea (Sacc.) Butin } \\
\text { (anamorph Dothichiza populea) }\end{array}$ & Branches and trunk & ++ \\
\hline 2. & Marssonina brunnea (Ell. et Ev.)P. Magn. & Leaves and sprouts & +++ \\
\hline 3. & Melampsora allii-populina Kleb. & Leaves & +++ \\
\hline 4. & Melampsora larici-populina Kleb. & Leaves & +++ \\
\hline 5. & Phyllosticta populorum Sacc. et Roum. & Leaves & ++ \\
\hline 6. & Pollaccia elegans Serv. & Leaves and sprouts & + \\
\hline 7. & Taphrina aurea (Pers.) Fr. & Leaves & +++ \\
\hline 8. & Valsa sordida Nitschke & Trunk & +++ \\
\hline 9. & Fomes fomentarius (L.) Fr. & Assortments and stumps & +++ \\
\hline 10. & Pholiota populnea (Pers.:Fr.) & Trunk and branches & +++ \\
\hline 11. & Trametes suaveolens (L.) Fr. & Thynk & + \\
\hline
\end{tabular}

(-) Typical saphrotrophes; $(+)$ present often, low economic impact; $(++)$ very often present in plantations, exceptionally cause practical problems; $(+++)$ practical problem in maintenance of poplar plantations. 


\section{DISSCUSION}

Poplar plantations have a high productivity and, in terms of forestry, short rotations (10-25 years). But, their economic profitability is far less than that found in industry and agriculture $[18,6]$. Serbia produces around $350000 \mathrm{~m}^{3}$ of poplar wood, which is much less than the world greatest producers like China, France, India, Italy and Turkey [25].

On the other side, long production cycles, provide low values for NPV, even for the discount rate of $r=4 \%$. Based on the above, it is clear that, in practice, it is necessary to improve the position of production in getting the deficient financial means for investments in poplar cultivation, in order to stimulate establishment of artificial poplar plantations, especially in the private sector [26]. Investments can be directed in cost reduction for: soil preparation (stump chipping, deep ploughing, etc.), improvement of inter-row tilling, better plant protection against insect pests and pathogenic fungi [27] Additional income and cost reduction can be obtained by using remaining poplar wood for biomass [28], which is in line with the Common Agricultural Policy of the European Union and endeavours of the Government of the Republic of Serbia to develop the bioenergy sector [29]. However, it is clear that the results have practical application, as they show in which interval poplar plantations are profitable.

It is also very important to mention that poplar plantations can not be profitable at discount rates in the range $10-15 \%$, as used in assessing funding opportunities in the economies of developing and transition countries [30]. The values of IRR in the work of various authors range from $4.3 \%$ [31] through 6-10\% [32] up to $12-15 \%[33,34]$ for poplar plantations. In our studied plot it is 6.94 . The costs of logging and assortment production make a significant expense item; an increase in costs of $20-40 \%$ (which can be expected due to the uncertain changes in the price of fuel and lubricants) may cause the IRR to increase by $2 \%$ [1]. These observations provide space for cost reduction in the felling and preparation of assortments and in the first phase of transport by wider use of automation (processors and "grinders"), or by transforming the entire timber mass into biomass $[35,36]$.

Average "benefit-cost" value is in the range from 0.4 to 2.8 [37] and our studied plot is it 0.407 .

Different authors analyze different $P B P$ for poplar plantations depending on the soil type, age of stand, plant density and climate. In India Dhillon et. al. [38] mention PBP of 7 years, Chandra about 10 years [39], McKenney in the range 10-22 years [40] and Latif et.al. [41] mention 15 years for poplar plantations in Malaysia.
Only application of all four methods gives solutions to investment issues in poplar plantations in general. The observed characteristics, such as soil type and age, are the directions for the establishment of intensive poplar plantations in the future. It is also very important to mention that depending on the purpose of plantations and market conditions, it is necessary to shortened rotation period on 15-20 years in respect to the current prescribed period of 25 years of poplar plantations in Serbia.

The investments can be directed to: more efficient soil preparation (stump chipping, deep ploughing, etc.), improvement of inter-row tilling, better plant protection against insect pests and pathogenic fungi. On the sites unsuitable for poplar planting, it is recommended to apply fertilizers, branch pruning to the height as much as 6 to $8 \mathrm{~m}$. All the above technical and technological measures, although classified as direct costs, contribute to the improvement of project efficiency, because they are directly reflected to the quality of assortments and their value at the end of the production cycle.

Based on the above, it is clear that the results have practical application, because shows in which interval poplar plantations are profitable. There are commercial banks in Serbia, where one can get a loan with interest rate of $5 \%$. Private owners can be advised to invest in such a production of poplar wood. On the other side there is the interest of state regarding poplar plantations. Plantations are very efficient in $\mathrm{CO}_{2}$ consuming, as shelterbelts, flood control, etc. Therefore, state can stimulate the forest owners to invest in poplar production in river banks in the future. The plantations grown on more quality soil types such as alluvial semigley are more profitable.

Nowadays, with the higher awareness of human impact on the environment, benefit/cost analysis is increasingly applied in the evaluation of forest social functions, wildlife conservation, impact on water resources (water supply, acidification and erosion control), landscape management, and greenhouse effect reduction. Forestry is often unable to valorize all of its products on the market, therefore the social community should support forestry, in a way, especially in the realization of the projects dealing with plantation forestry. One of the forms of support could be to enable the use of beneficial interest rates on the means invested in the establishment of new plantations, which are considerably lower than those in other production fields.

Losses from the pests and pathogens in hybrid poplar plantation are almost unavoidable [42]. Some year environmental conditions can speed up inoculum production and cause epidemic [43]. Because of high costs 
of poplar plantation establishment all losses from pests and diseases must be kept as low as possible. Special attention must be devoted to the survival of seedlings in the first vegetation after planting. It was observed that under the moderate attack of leaf pathogens [44], as it was the case in this study, there is no significant loss of height and diameter increments $[45,13]$.

\section{CONCLUSIONS}

On the basis of the analysis performed using the NPV method, it can be concluded that the studied plot for the time period of 26 years was unprofitable, because the loss was about $1586 € \cdot \mathrm{ha}^{-1}$. Investments in the plantations of these rotations are acceptable only if the discount rates (4-6)\%. Based on application of the susceptibility analysis, it was concluded that positive financial effects can be realized by decreasing costs, or by increasing receipts. The research showed that the IRR for sample plot is 6.94. Sensitivity analysis of IRR shows that the stand is very susceptible to changes of incomes and outcomes. The analysis shows that
$P B P$ is practically unacceptable for the investor under the discount rate of $6 \% . R$ is 0.407 at a discount rate of $12 \%$, therefore it can be claimed that it is economically unacceptable to invest in such stand.

Application of intense protection measures during the first three years can prevent increase of costs by necessity for replacing dead trees. Further protection of leaves against pests and diseases can improve both tree conditions and prevent losses in height and diameter increment. Maximal production will result in as high income as it can be expected from the site potential.

\section{Acknowledgment}

This research was supported by grant from the Ministry of Education and Science of the Republic of Serbia. We would like to that to the projects: "Sustainable management of total forests potential in the Republic of Serbia" (TR 37008) and "Forest plantations as the indicator of increasing afforestated areas of Serbia" (TR 31041).

\section{REFERENCES}

1. ROSE D, FERGUSON K, LOTHNER D C, ZAVITKOVSKI J 1981 An economic and energy analysis of poplar intensive cultures in the Lake States. North Central Forest Experiment Station Forest Service, U.S. Department of Agriculture, USDA Forest Service, Research paper NC-196

2. LOTHNER D C 1983 Economic investigations of short rotation intensively cultured hybrid poplars. In: Hansen E A (eds) Intensive Plantation Culture: 12 years of Research USDA Forest Service GTR NC-91, pp $139-148$

3. BOYSEN B, STROBL S 1991 A growers guide to hybrid poplar. Ontario Ministry of Natural Resources, Toronto, Ontario, Canada

4. VOLNEY W J, ALFARO R I, BOTHWELL P, HOGG E H, HOPKIN A, LAFLAMME G, HURLEYJ E, WARREN G, METSARANTA J, MALLETT K I 2005 A framework for poplar plantation risk assessments. Unasylva 56: 20-25

5. OOSTEN C 2006 Hybrid poplar crop manual for the prairie provinces. Saskatchewan Forest Centre, Prince Albert, SK and Poplar Council Canada, Edmonton, AB, Canada

6. ISEBRANDS J G 2007 Best Management Practices Poplar Manual for Agroforestry Application in Minnesota. USDA, Washington, p 61

7. PETRÁŠ R, MECKO J, NOCIAR V 2008 Value production of poplar clones. Journal of Forest Science 54 (6): 237-244

8. KEČA $\sqcup$ 2010a Estimation of cost-effectiveness of poplar wood production in Ravni Srem by applying the net present value method. Bulletin of the Faculty of Forestry University of Belgrade 101: 81-100.
9. KEČA $\sqcup 2011$ a Estimation of cost-effectiveness of poplar wood production in poplar plantations in ravni srem based on the method of pay back period. Bulletin of the Faculty of Forestry University of Belgrade 103: 41-56.

10. KEČA $\sqcup 2011$ b Estimation of cost-effectiveness of poplar wood production in poplar plantations in Ravni Srem based on the cost-benefit method. Bulletin of the Faculty of Forestry University of Belgrade 104: 81-96.

11. KEČA $\sqcup$ 2010b Assessment of cost-efficiency for wood production in poplar plantations in Ravan Srem, based on internal rate of return. Bulletin of the Faculty of Forestry University of Belgrade 102: 25-40.

12. KEČA ப, KEČA N, PAJÍ S 2011 Investment Appraisal of Poplar Plantations in Serbia. Baltic For 17 (2): 268-279

13. CELLERINO G P, GENNARO M 1999 Review of poplar diseases. International Poplar Commision, FAO, Rome

14. KEČA N 2003a Possibility of parasite (Marssonina brunnea (Ell.\& Ev.)P. Magnus and Melampsora spp.) control on poplar foliage with some fungicides, Bulletin of the Faculty of Forestry University of Belgrade 88: 103-120, DOI:10.2298/ GSF0388103K (in Serbian with English summary)

15. KEČA N 2000 The most frequent diseases in poplar plantations in the region of Potisje, Bulletin of the Faculty of Forestry University of Belgrade 82: 81-91 (in Serbian with English summary)

16. SHARMA R C, SHARMA S, GUPTA A K 2005 Effect of preventative fungicide sprays on Melampsora rust of poplar in the nursery. In: Pei H M, McCracken A R (eds) Rust diseases of willow and poplar. CABI Publishing, pp 209-212 
17. KEČA L, PAJĆ S 2010 Financial Aspects of Restoration in Poplar Plantations with Technology of Full Ground and Soil Preparation, International Conference "Land Conservation"- LANDCON 0905 - May 26-30, 2009 Tara Mountain/Serbia - in Global Change Challenges for Soil Management, Advances in Geology 41, Editor Miodrag Zlatic, Catena Verlag $\mathrm{GmbH}$, pp 321-334

18. GITTINGER P 1972 Economic Analysis of Agricultural Projects. The Economic Institute, International Bank for Reconstruction of Development, The John Hopkins University Press, Baltimore-London

19. LUMBY S 1988 Investment Appraisal and Financing Decisions. Third Ed. Van Nostrand Reinhold Co.Ltd, England

20. POGUE M 2010 Corporate Investment Decisions Principles and Practice. Business Expert Press, New York, USA

21. GÖTZE U, NORTHCOTT D, SCHUSTER P 2008 Investment Appraisal-Methods and Models. Springer-Verlag Berlin

22. KEČA $\sqcup 2005$ Analysis of commercial cost-effectiveness of poplar plantations. Bulletin of the Faculty of Forestry University of Belgrade 91: 135-147.

23. KEČA N 2004 Mycoflora diversity in the stands and plantations of poplars in the section Aigeiros. Bulletin of the Faculty of Forestry University of Belgrade 90: 109-118, DOI:10.2298/GSF0490109K (in Serbian with English summary)

24. KARADŽIĆ D 1987 Influence of pathogenic mycoflora on declining of treees in Pinus spp. plantations. Forestry (Belgrade) 5: $89-106$

25. SPINELLI R, MAGAGNOTTI N 2011 Strategies for the processing of tree tops from hybrid poplar plantations. Baltic For 17: 50-57.

26. JAMES R, DEL LUNGO A 2005 The Potential for Fast-Growing Commercial Forest Plantations to Supply High Value Roundwood. FAO, Planted Forests and Trees Working Papers, Working Paper 33. Forest Resources Development Service, Forest Resources Division. FAO, Rome

27. KEČA N 2008 Diseases in poplar plantations. Bulletin of the Faculty of Forestry University of Belgrade 97:7-31 (in Serbian with English summary)

28. SPINELLI R, NATI C, MAGAGNOTTI N 2005 Harvesting and transport of root biomass from fast-growing poplar plantations. Silva Fennica 39: 539-548

29. KEČA U, KEČA N, PANTIĆ D 2012 Net Present Value and Internal Rate of Return as indicators for assessment of costefficiency of poplar plantations: a Serbian case study. Int For Rev 14 (2): 1-12

30. 2005. Serbia and Montenegro: Selected Issues and Statistical Appendix. IMF, Country Report No. 05/232, Washington D.C., USA, p 127

31. ANDERSON J A, LUCKERT M K 2006 Can hybrid poplar save industrial forestry in Canada's boreal forest? A financial analysis and policy considerations. Western Forest Economist Meeting, Oregon
32. TANKERSLEY L 2006 Hardwood Plantations as an Investment. University of Kentucky's Cooperative Extension publication FOR-101

33. TABBUSH P, BEATON A 1998 Hybrid poplars: present status and potential in Britain. Forestry 71: 355-364

34. JAIN S K, SINGN P 2000 Economic analysis of industrial agroforestry: poplar (Populus deltoides) in Uttar Pradesh (India). Agroforest Syst 49: 255-273

35. ERIKSSON H M, HALL J P, HELYNEN S 2002 Bioenergy from sustainable forestry: Guiding principles and practice. In: Richardson J, Björheden R, Hakkila P, Lowe A T, Smith C T (eds), Kluwer Academic Publishers, The Netherlands, pp 1-17

36. WHITEMAN A, BROWN C, BULL G 1999 Forest product market developments: the outlook for forest product markets to 2010 and the implications for improving management of the global forest estate. Working Paper FAO/ FPIRS/02, Food and Agriculture Organization of the United Nations, Rome

37. SIDDIQUI K M, KHAN F S 1991 In term Financial Analyses of on station intercropping study. Pakistan Journal Forestry 41 (2): 157-164

38. DHILLON A, VINOD S, MAHK D P, DHILLON M S 2001 An economic analysis of poplar cultivation. Indian Forester 127 (1): 86-90.

39. CHANDRA J P 1986 Poplar: A Cash Crop for North Indian Farmers. Indian Forester 112(8): 698-710

40. MCKENNEY D W, YEMSHANOV D, FRALEIGH S, ALLEN D, PRETO F 2011 An economic assessment of the use of short-rotation coppice woody biomass to heat greenhouses in southern Canada. Biomass and Bioenerg 35 (1): 374-384

41. LATIF J, MOHD N M, TAYEB D M, KUSHAIRI D A 2003 Economics of Higher Planting Density in Oil Palm Plantations, Oil Palm Industry. Econ J 3 (2): 32-39

42. MINGHAO P, YANZHONG S 2005 A brief summary of Melampsora species of Populus. In: Pei H M, McCracken A $\mathrm{R}(e d s)$ Rust diseases of willow and poplar. CABI Publishing, pp 51-63

43. KARADŽIĆ D, MILIJAŠEVIĆ T 2005 The most frequent powdery mildews on forest woody species and their impact, Bulletin of the Faculty of Forestry University of Belgrade 91: 9-29, DOI:10.2298/GSF0591009K(in Serbian with English summary)

44. ROYLE D J, OSTRY M E 1995 Diseases and pest control in the bioenery crops poplar and willow. Biomass and Bioenerg 9: 69-79

45. KEČA N 2003b Test of resistance of Populus $x$ euramericana cv. Pannónia to the attack of Discosporium populeum (Sacc.) Sutton in the conditions of Gornje Potisje, Bulletin of the Faculty of Forestry University of Belgrade 87: 139-149, DOI:10.2298/GSF0387139K (in Serbian with English summary) 
